\title{
Comparative Study of Three Different Modern Drugs against Trichostrongylosis in Goats
}

\author{
N.R. Rajpura ${ }^{1}$, G.C. Mandali ${ }^{1}$, S.K. Raval ${ }^{1 *}$ and D.M. Patel $^{2}$ \\ ${ }^{1}$ Department of Veterinary Medicine, ${ }^{2}$ Department of Veterinary Clinical Complex, College of \\ Veterinary Science and Animal Husbandry, AAU, Anand-388 001, Gujarat, India \\ *Corresponding author
}

\section{A B S T R A C T}

\begin{tabular}{|l|}
\hline K e y w o r d s \\
Anthelminticss, \\
Micrometry, \\
Coproculture, EPG, \\
Trichostrongylus spp., \\
Goat
\end{tabular}

\section{Introduction}

The domesticated goat is sociable, inquisitive and intelligent species, which has been used for its milk, skin and fur. Goat is a versatile animal known as the "Poor man's cow" in India and wet nurse of infants in Europe. Archaeological studies provide sufficient evidence that goat was the earliest ruminant and probably the first animal after dog to be domesticated by man long before 7000 B.C. The disease caused by Trichostrongylus worms is called trichostrongylosis or trichostrongyliasis. Trichostrongylus also

\begin{abstract}
The study aimed to assess the study of three different drugs against trichostrongylosis in goats. There were 4 groups, Group A served as the healthy control $(n=8)$, group B, C and D kept as the treatment group and each group having 16 goats. Group B, C and D were treated with Fenbendazole, Levamisole and Ivermactin respectively. For identification of Trichostrongylus spp. micrometry and coproculture of the samples were performed. The therapeutic efficacy was evaluated through determination of eggs per gram (EPG) count. Faecal sample were collected before treatment and $14^{\text {th }}$ days after treatment of study. Pre and post-treatment EPG values were recorded and compared the result showed that on the basis of comparative efficacy of different drugs, the therapeutic use of Susp. Fenbendazole orally @ $7.5 \mathrm{mg} / \mathrm{kg}$ body weight with supportive therapy and better management practices was emerged out as the effective modality in resolving trichostrongylosis in goats.
\end{abstract}


ivermactin have been studied (Godara et al., 2011, Jaiswal et al., 2013, Das et al., 2016). Much gastrointestinal nematode developed resistance against anthelmintic drugs and the drugs are not effective to control the worm infection, lead to high mortality in infected goats. Hense the present study was conducted to ascertain the incidence of trichostrongylosis infection in goat and its therapeutic management.

\section{Materials and Methods}

About48 clinical cases of trichostrongylosis in goats brought to the Veterinary Clinical Complex, Anand as well as by door to door visits of villages nearby Anand. The cases having the history of diarrhoea, anorexia, weakness and not dewormed were selected. The clinical examination was carried out and faecal samples were collected from such cases for microscopic examination. Those cases having presence of eggs and/or larvae of Trichostrongylus spp. were included in this study. For therapeutic trials, 48 naturally infected goats wit trichostrongylosis were allocated into 3 groups B, C and D, having 16 animals in each group. Goats of group B were treated with Fenbendazole @ $7.5 \mathrm{mg} / \mathrm{kg}$ body weight orally, Group $\mathrm{C}$ with the Levamisole @ $12 \mathrm{mg} / \mathrm{kg}$ body weight orally and Group D with Injection Ivermectin @ $200 \mu \mathrm{g} / \mathrm{kg}$ body weight subcutaneously. All goats were given supportive treatment as per requirement.

Faecal samples were collected from infected goats on 0 -day before the treatment and $14^{\text {th }}$ day after the treatment for egg count to evaluate the comparative efficacy of drugs. The EPG was counted by Mac-Master chamber method. For identification of Trichostrongylosis spp micrometry and coproculture of faecal sample was carried out on day- 0 and $14^{\text {th }}$ day post treatment. Eggs were examined microscopically and measurements were taken by using $10 \mathrm{X}$ graduate eye piece and 40X objective lens. The data were compared by employing student's paired ' $\mathrm{T}$ ' test for variations between healthy and infected goats. The data were compared by employing student's paired ' $\mathrm{T}$ ' test for variations between healthy and infected goats.

\section{Results and Discussion}

Eggs were oval, thin shell and segmented on microscopic examination and measurements were taken by using $10 \mathrm{X}$ graduate eye piece and 40X objective lens and the average size were study result were in line with the result of (Soulsby., 2005).

On coproculture sufficient number of larva/e could be obtained for identification. The study revealed the morphological characters of anterior end was broad, rounded and tail end was short, conical and blunt at the tip of the tail. The average total larval length were about 640-650 $\mu \mathrm{m}$ in size. Average tail sheath length was 30-35 $\mu \mathrm{m}$. The larvae of Trichostrongylus spp. in present study result were in line with the result of Indre et al., (2009) and Sharma (2012).

The goats of Group B were treated with Susp. Fenbendazole @ $7.5 \mathrm{mg} / \mathrm{kg}$ body weight orally and the mean value of EPG pre and post treatment was $531.25 \pm 15.05$ and $75.00 \pm 19.36$ (Table 1). Reduction of EPG on the $14^{\text {th }}$ day in infected goats. This result was found by earlier workers Bansal. (1981), Haq et al., (1984), Rahmatulla et al., (1985) reported that fenbendazole at the dose rate of $5 \mathrm{mg} / \mathrm{kg}$ body weight on goats was $100 \%$ effective after 5 days of treatment. The reduced efficacy of fenbendazole drugs against gastrointestinal nematode parasite in goats has been well documented by Yadav et al., (2005), Ram et al., (2007). Contrary to this fenbendazole was found to be most effective against trichostrongylosis in goats in present study. 
Table.1 Effect of different modern anthelmintics on egg count (EPG) in goats

\begin{tabular}{|c|c|c|c|}
\hline Group & Drug with dose & $\begin{array}{c}\text { Pre treatment } \\
(\mathbf{0} \text {-day })\end{array}$ & $\begin{array}{c}\text { Post treatment } \\
\left(\mathbf{1 4}^{\text {th }} \text { day }\right)\end{array}$ \\
\hline B & $\begin{array}{c}\text { Fenbendazole } \\
7.5 \mathrm{mg} / \mathrm{kg} \mathrm{BW} \mathrm{PO}\end{array}$ & $531.25 \pm 15.05$ & $75.00 \pm 19.36^{* *}$ \\
\hline C & $\begin{array}{c}\text { Levamisole } \\
\text { Hydrochloride } \\
12 \mathrm{mg} / \mathrm{kg} \mathrm{BW} \mathrm{PO}\end{array}$ & $450.0 \pm 27.38$ & $50.00 \pm 12.90^{* *}$ \\
\hline D & $\begin{array}{c}\text { Ivermectin } \\
200 \mu \mathrm{g} / \mathrm{kg} \mathrm{BW} \mathrm{S/C}\end{array}$ & $481.25 \pm 18.75$ & $62.50 \pm 17.96^{* *}$ \\
\hline${ }_{* *}^{*}(\mathrm{p}<0.01)$ & & & \\
\hline
\end{tabular}

The goats of Group C were treated with Pulv. Levamisole Hydrochloride @ $12 \mathrm{mg} / \mathrm{kg}$ body weight orally and the mean value of EPG pre and post treatment was $450.0 \pm 27.38$ and $50.00 \pm 12.90$ (Table 1). Reduction of EPG on the $14^{\text {th }}$ day in infected goats. This result was found by earlier worker (Jaiswal et al., 2013). Manikkavasagan et al., (2015) reported that levamisole have been regularly and widely used in India for control parasitic gastroenteritis in goats for last 2-3 decades.

The goats of Group C were treated with Inj. Ivermactin @ $200 \mu \mathrm{g} / \mathrm{kg}$ body weight subcutaneously and the mean value of EPG pre and post treatment was $481.25 \pm 18.75$ and $62.50 \pm 17.96$ (Table 1). Reduction of EPG on the $14^{\text {th }}$ day in infected goats. This result is in related with the earlier researchers (Mukherjee et al., 1994, Singh et al., 1994, Ram et al., 2007, Godara et al., 2011, Akanda et al., 2014). Yadav et al., (1996) reported that $99-100 \%$ efficacy of ivermactin on nematodes in sheep and goats. To some up, Fenbendazole, Levamisole and Ivermactine are effective for reduction of EPG Trichostrongylus spp. in goats. Among these three modern anthelmintics the therapeutic use of Susp. Fenbendazole orally @ 7.5 $\mathrm{mg} / \mathrm{kg}$ body weight with supportive therapy and better management practices was emerged out as the effective modality in resolving trichostrongylosis in goats.

\section{References}

Akanda, M. R., Islam, M. S., and Howlader, M. M. R. (2014). Comparative efficacy of three different modern drugs against nematodiasis in goat. Wayamba Journal of Animal Science, 6, 963-968.

Bansal, S.R., Gautam, O.P., and Deyhazra, (1981). Trials with fenbendazole in natural gastrointestinal nematodiasis in sheep. J. Vet. Parasitol. 20:57-59.

Das, A. K., Ajit, K., Sinha, R. K., and Samantray, S. (2016). Incidence of gastrointestinal helminth parasites in goats and their therapeutic management. Veterinary Science Research Journal, $7(1), 62-65$.

Godara, R., Sharma, R. L., and Sodhi, S. S. (2011). Efficacy of fenbendazole, levamisole and ivermectin against gastrointestinal nematodes in Jamunapari goats. Journal of Parasitic Diseases, 35(2), 219-221.

Haq, S., Verma, B. B., and Thakur, D. K. (1984). Efficacy of fenbendazole against mixed infections with gastrointestinal nematodiasis in goats. Indian Veterinary Journal, 61: 509-511.

Indre, D., Darabus, G. H., Oprescu, I., Morariu, S., Narcisa, M., Ilie, M. S., and Mandita, D. N. (2009). The identification of gastrointestinal nematodes species in sheep in five 
localities from Timis County. Lucrari Stiintifice Medicina Veterinara, 6 (1): 94-100.

Jaiswal, A. K., Sudan, V., Shanker, D., and Kumar, P. (2013). Emergence of ivermectin resistance in gastrointestinal nematodes of goats in a semi-organized farm of Mathura district, India. Veterinary Arhiv, 83(3), 275-280.

Kaplan, R. M. (2016). Sustainable Integrated Parasite Management in Small Ruminant Parasites. University of Georgia Athens, Georgia, 30602.

Manikkavasagan, I., Binosundar, S. T., and Raman, M. (2015). Survey on anthelmintic resistance to gastrointestinal nematodes in unorganized goat farms of Tamil Nadu. Journal of Parasitic diseases, 39(2), 258-261.

Mukherjee, R., Laha, R., Bhattacharya, D., and Reena, M. (1994). Comparative efficacy of tetramisole, Fenbendazole and Ivermectin against gastrointestinal nematode infection in Pashmina (Cashmere) goats. Indian J. Anim. Health, 33, 125-127.

Rahmatulla, P. S., Rajasudharam, R. C., Suresh, R.V. and Nagarujarn, R. (1985). Effect of Fenbendazole as anthelmintic of goats. Indian Vet. J., 52:993-995

Ram, H., Rasool, T. J., Sharma, A. K., Meena, H. R., and Singh, S. K. (2007). Comparative efficacy of different anthelmintics against fenbendazoleresistant nematodes of Pashmina goats. Veterinary research communications, 31(6), 719-723.
Risso, A., Kessler, J. D., Soriano, V. S., Nunes, M. L. A., Machado, G., Langaro, A., and Volpato, A. (2015). Influence of pathological conditions caused by gastrointestinal parasites infection on pregnant ewe' $\mathrm{s}$ behavior. Acta Scientiae Veterinariae, 43(1), 1-7.

Sharma, S. (2012). Studies on prevalence, clinico-biochemical and histopathological aspects of helminth parasites of goats in anand district (Doctoral dissertation, Anand Agricultural University, Anand).

Singh, J., Gill, J. S., Ramneck, and Kwatra, M. S. (1994). Comparative efficacy of anthelmentics against natural nematodes infections of sheep and goats in Punjab. J. Vet. Parasitol. 8: 47-50.

Snedecor, G.W. and Cochran, W.G. (1980). Statistical methods, $6^{\text {th }}$ Ed., Oxford and JBH Publishing, New York.

Soulsby, E.J.L. (2005). Helminths, Arthropods and Protozoa of Domesticated Animals. 7th Edition, ELBS and Bailliere Tindall, London, pp $239-240$.

Yadav, C. L., Banerjee, P. S., Garg, Y., and Vatsya, S. (2005). All India network program on gastrointestinal parasitism establishment of epidemiology of important parasitic diseases. J. Vet. Parasitol, 89(9): 1518-1523.

Yadav, C. L., Ghouri, S. K., Singh, B. P., and Sharma, M. C. (1996). Benzimidazole resistance in sheep and goats in haemonchus contortus of sheep and goats in Uttar Pradesh in India. Journal of Veterinary Parasitology, 10, 47-51.

\section{How to cite this article:}

Rajpura, N.R., G.C. Mandali, S.K. Raval and Patel, D.M. 2018. Comparative Study of Three Different Modern Drugs against Trichostrongylosis in Goats. Int.J.Curr.Microbiol.App.Sci. 7(10): 3004-3007. doi: https://doi.org/10.20546/ijcmas.2018.710.349 